\title{
J. H. Newman - \\ uloga sveučilišta u intelektualnom i moralnom razvoju čovjeka
}

\author{
Maja POLJAK \\ UDK: 1:37 Newman, J.H. • Prethodno priopćenje \\ Primljeno: 21. travnja 2017. • Prihvaćeno: 23. studenoga 2017.
}

Sažetak: Obrazovanje spada među jedno od najvažnijih sredstava razvitka ljudskog intelektualnog potencijala. Bilo da je riječ o formalnom ili neformalnom obrazovanju, ono je uvijek igralo važnu ulogu kako u životu pojedinca, tako i u životu zajednice. U radu koji je pred nama autorica tematizira neke osnovne principe obrazovne teorije engleskog mislioca J. $H$. Newmana. U prvom poglavlju rada riječ je o čovjeku shvaćenom kao biću razvoja koje treba odredena pomoćna sredstva za dostizanje intelektualne izvrsnosti. Medu tim sredstvima obrazovanje zauzima jedno od prvih mjesta. U drugom poglavlju iznesen je Newmanov stav prema utilitaristickoj koncepciji sveučilišne naobrazbe, dok treće poglavlje tematizira

* Dr. sc. Maja Poljak, Odjel za filozofiju Sveučilišta u Zadru, Obala kralja Petra Krešimira IV. br. 2, 23000 Zadar, Hrvatska, mpoljak@unizd.hr utjecaj sveučilišta na moralni razvoj pojedinca.

Ključne riječi: obrazovanje, sveučilište, Newman, intelektualni razvoj, moralna formacija, utilitarizam.

\section{Uvod}

Obrazovanje, najopćenitije govoreći, možemo podijeliti na dvije vrste: formalno i neformalno. Formalno je povezano s prenošenjem znanja u specijaliziranim ustanovama (školama) u kojima je sadržaj učenja strogo definiran i sistematiziran te prenošen od onih koji su za to posebno školovani. Neformalno obrazovanje, s druge strane, označava svaki drugi oblik prenošenja znanja koje rezultira razvojem intelektualnih sposobnosti, stjecanjem novih vještina, formiranjem moralnog i intelektualnog karaktera osobe. U ovom obliku obrazovanje postoji od samih ljudskih početaka te, za razliku od formalnoga, ono nije vremenski ogra- 
ničeno. Dapače, temelji se na principu »čovjek uči dok je živ« te se promatra kao cjeloživotni proces. Bilo da je riječ o formalnom ili neformalnom, obrazovanje se uvijek promatralo kao jedno od primarnih pridonositelja ljudskoga razvoja koji pomažu čovjeku ispuniti svoje potencijale.

Budući da je obrazovanje prije svega usmjereno na čovjeka, ono se treba temeljiti na dobrom poznavanju istoga, tj. na poznavanju njegove naravi, mogućnosti, dostojanstva i cilja. No, kako uz čovjeka ono također ima u vidu i dobrobit zajednice kojoj taj pojedinac pripada, onda je jasno da je prilikom definiranja cilja i sadržaja obrazovanja potrebno obratiti pozornost na društveni aspekt cjelokupnog procesa. Pravi je izazov stoga pronaći ravnotežu koja će zadovoljiti potrebe i ciljeve jednoga i drugoga s namjerom izbjegavanja neravnoteže koja bi bila štetna ne samo za pojedinca nego i za društvo. Naime, ako obrazovni sustav u prvi plan stavi čovjeka promatranog isključivo kao pojedinca, ne obazirući se na potrebe društva kojem pripada i utjecaj što će ga u njemu imati, onda će taj sustav težiti razvoju svih potencijala koji će čovjeku kao individui pomoći, pritom zanemarujući činjenicu da je on i društveno biće koje je pozvano brinuti se ne samo za osobno nego i za opće dobro. Samim time ovakav će obrazovni sustav direktno naštetiti društvu, jer će odgajati i obrazovati pojedince koji neće doprinositi boljitku društva, nego isključivo boljitku vlastitog života. U situacijama kada učine nešto za dobrobit društva, razlog ćemo za to naći u činjenici da su sami od toga imali koristi. No, u onim trenutcima kada te osobe budu pozvane birati između vlastitog interesa ili nekog društvenog dobra, možemo s visokim postotkom vjerojatnosti pogoditi u kojem će smjeru njihov izbor ići. Važno je, međutim, napomenuti da ovakav način ponašanja, osim što direktno nanosi štetu društvo, indirektno nanosi štetu i samom pojedincu koji će propustiti priliku oplemeniti svoj život služeći drugima s kojima je po svojoj društvenoj naravi povezan.

$S$ druge strane, u prvi plan obrazovnog sustava može doći društvo shvaćeno kao cjelina nadređena pojedincu. Takav će obrazovni sustav za svoj cilj prije svega imati dobrobit društva kojem će podčiniti obrazovanje pojedinaca školovanih radi osiguranja boljih ekonomskih, političkih, praktičnih ili kojih drugih uvjeta života zajednice, pritom zanemarujući osobne preferencije, želje i potrebe osobe. Vidljivo je kako ovako postavljen obrazovni sustav šteti samom čovjeku koji se promatra samo kao jedan dio veće cjeline u čiju je službu stavljen. No, kao u prethodnom slučaju šteta na jednom području po nužnoj vezi prelazi i na drugo. Ako je u prvoj vrsti obrazovanja riječ bila o direktnoj šteti za društvo i indirektnoj šteti za pojedinca, u ovoj je situaciji stvar obrnuta te govorimo o direktnoj šteti za pojedinca i indirektnoj šteti za društvo. Jasno je da zanemarivanjem osobnih preferencija, želja, mogućnosti i potreba pojedinca štetimo toj osobi, no isto tako štetimo i društvu kojem pripada jer stvaramo cijeli niz nezadovoljnih, neispunjenih i potlačenih ljudi 
koji kao takvi ne mogu pozitivno djelovati na zajednicu u onim aspektima njezinog života koji su važniji od ekonomskog probitka ili političke moći.

Ideal, prema običaju, leži negdje između dva postavljena ekstrema, stoga bi svaki obrazovni sustav, ako želi biti dobar, kvalitetan i uspješan, trebao obratiti pozornost na osobni i društveni aspekt cjelokupnog procesa. Sukladno tome, prilikom definiranja svrhe obrazovanja, obrazovnih ciljeva i sadržaja, obratit će se pozornost na potrebu da se pojedinac kojeg obrazujemo usavrši za svoje dobro i za dobro zajednice kojoj pripada.

Rad koji je pred nama predstavlja jedan dio obrazovne teorije engleskog mislioca J. H. Newmana koji je cijeli svoj život bio zainteresiran za spomenutu temu ${ }^{1}$. Ovdje ćemo se prije svega fokusirati na visokoškolsko obrazovanje te na neke njegove dobrobiti za pojedinca -posebno za njegov intelektualni i moralni napredak - a iz toga će biti vidljiva i dobrobit koju društvo kao takvo od ovog pojedinca može imati.

Prema Newmanu važnost bilo kojeg obrazovanja proizlazi prije svega iz činjenice da ono predstavlja veliko dobro ne samo za razvoj znanosti i društva nego ponajviše za samog pojedinca koji se obrazuje. Utemeljenje za to on pronalazi u konstituciji čovjeka promatranog kao biće obdareno razumom - uzvišenom spoznajnom moći koju je potrebno cijeli život razvijati i obogaćivati, a obrazovanje spada među nužna sredstva za to. Stoga ćemo u prvom poglavlju obraditi dio Newmanove obrazovne teorije koja polazi od shvaćanja čovjeka kao bića razvoja ${ }^{2}$.

\footnotetext{
${ }^{1}$ Njegov interes za obrazovanje datira iz vremena kada je predavao na Oxfordu i u to je vrijeme već imao jasnu ideju o tome što sveučilišno obrazovanje može učiniti za mladu osobu. Kad je u svojim 40-ima prešao iz anglikanske crkve u katoličku, pitanje je sveučilišnog obrazovanja postalo još važnije i u njegovim privatnim spisima nalazimo zapis: »Od početka do kraja obrazovanje je bilo moja nit vodilja « (J. H. NEWMAN, Autobiographical Writings, New York, 1957., 259.). Godine 1850. Newmana je biskup P. Cullen pozvao u Irsku, radi osnivanja katoličkog sveučilišta, te je Newman odmah pristao jer je to vidio kao priliku podizanja intelektualne razine katolika u Velikoj Britaniji koji su zbog restrikcija izgubili mnoge povlastice u tom društvu, a među njima i povlasticu pohađanja elitnih sveučilišta koja su bila državna (usp. M. POLJAK, Newmanovo shvaćanje sveučilišta kao mjesta intelektualne formacije, u: Acta Iadertina (2015.)2, 127.-139., ovdje 129.-130.

2 Pojam 'razvoj' predstavlja jedan od najvažnijih pojmova Newmanove misli, počevši od njegovog teološki najutjecajnijeg djela Razvoj kršćanske doktrine. Razvoj označava složenu realnost prirodne i nužne promijene i rasta koji je povezan sa životom kao posebnom vrstom postojanja. Život kao posebna vrsta postojanja omogućava biću da sazrije u svoju savršeniju i potpuniju verziju preko aktualizacije svih potencijala koje posjeduje u sebi. Poticaj za razvoj primarno dolazi iznutra te je pod utjecajem mnogih faktora i prolazi kroz razne stadije. Ovaj unutarnji impuls proizlazi iz naravi samog bića koja se promatra s gledišta unutarnjeg dinamizma.
} 


\section{1. Čovjek - biće razvoja}

U svome djelu Logika pristanka Newman postavlja pitanje: »Koja je posebnost naše naravi u odnosu na niže životinje oko nas? To je činjenica da je čovjek, premda ne može promijeniti ono s čim je rođen, biće napretka s obzirom na svoje savršenosti i njemu karakteristično dobro. Druga su bića kompletirana od svoga početka u onim savršenostima koja su za njih specifična; ali čovjek započinje s ničim realiziranim (da se poslužim tom riječju) i mora stvoriti kapital za sebe koristeći one moći koje čine njegovo prirodno nasljedstvo. Tako postupno napreduje prema punini svoje prvobitne sudbine. $\ll^{3}$

Ovdje je čovjek prikazan kao biće koje se po naravi razvija i usavršava, no njegova je sudbina, za razliku od drugih živih bića, takva da on na neke segmente tog razvoja može utjecati te je za njih direktno odgovoran. Jedan je od tih segmenata intelektualni razvoj koji se jednim dijelom sastoji od pasivnog primanja i pohranjivanja informacija s kojima se tijekom života susrećemo, dok je drugi u vezi s aktivnim povezivanjem postignutog znanja u smislenu cjelinu te nadograđivanjem novoga na temelju što smo ga već stvorili. Bilo da je riječ samo o primanju novih spoznaja ili da je riječ o aktivnom povezivanju novoga sa starim, obrazovanje bi trebalo biti jedna od društvenih aktivnosti koja će nam u tome uvelike pomoći. Pitanje je samo koliko smo mi kao pojedinci spremni u njega uložiti.

Jasno je naime, da se čovjek razvija na raznim razinama - fizičkoj, psihičkoj, društvenoj, intelektualnoj itd. Isto je tako jasno da će se na nekim više razviti negoli na drugim, ovisno o tome koje talente i predispozicije posjeduje, kolike su mu društvene i materijalne mogućnosti, te koliki interes i motivaciju za određenu vrstu razvoja posjeduje. Razvoj na bilo kojoj od spomenutih razina pozitivna je i hvalevrijedna stvar, te ako su sve razine u razvoju usklađene, tako da nijedna ne napreduje na štetu druge, onda je osoba doista na putu optimalne aktualizacije svojih potencijala. Nažalost, to nije čest slučaj te nerijetko razvoj na jednoj razini označava stagnaciju ili nazadovanje na drugoj. Nedostatak vremena, mogućnosti ili interesa neki su od glavnih krivaca za to, stoga je ispravna prioritizacija iznimno važna tako da se možemo usredotočiti na one elemente koji su za čovjekovu dobrobit najvažniji.

Tradicionalno se velika važnost pripisivala razvoju intelektualnih i moralnih vrlina usmjerenih na usavršavanje dviju specifičnih ljudskih moći - razuma i volje - koje čovjeka bezgranično uzdižu iznad drugih živih materijalnih bića. Iz toga su razloga osnivane razne odgojno-obrazovne ustanove koje su za svoju zadaću imale pomoći pojedincu, a preko njega i cjelokupnom društvu, da napreduje u životu te izraste u ispunjenu i zadovoljnu osobu. Kada je riječ o sveučilišnom obrazovanju kao najvi-

${ }^{3}$ J. H. NEWMAN, An Essay in Aid of Grammar of Assent, Oxford, 1985., 225. 
šem stupnju formalnog obrazovanja, Newman ga je također gledao kao odgojnoobrazovnu ustanovu, iako je često veći naglasak stavljao na obrazovni dio zadatka. ${ }^{4}$

Kao što smo vidjeli, poticaj za razvoj i napredak na bilo kojoj razini dolazi iz same čovjekove naravi te, kada govori o razvoju intelektualnih sposobnosti, Newman razum promatra kao spoznajnu moć preko koje stječemo znanje. On je ljudski um vidio kao prazninu koju treba ispuniti, no ta praznina nije bila pasivna nego aktivna. To je praznina žive moći koja postoji zato da bi bila ispunjena svojim prirodnim objektom kojeg aktivno traži i nakon što ga nađe, zna točno što s njime treba učiniti. Spoznajne moći omogućuju nam da posegnemo za svijetom i da se njime ispunimo. Ovo se ispunjenje događa preko stjecanja znanja i zbog toga Newman u Ideji sveučilišta kaže da stjecanjem znanja mi zadovoljavamo direktnu potrebu naše naravi. ${ }^{5}$ Kao takvo znanje predstavlja nešto $\gg$ vrijedno zbog toga što sama njegova prisutnost u nama čini za nas $\ll^{6}$. Newman ovo još dodatno ističe kada kaže da je » poboljšanje naše naravi, bilo u nama samima bilo u ljudskom rodu, nešto što je za svakog... sveta dužnost «?

Obrazovanje označava jedno od sredstava kojim možemo postići ovaj razvoj i usavršavanje te ono kao takvo, kao što je već rečeno, mora biti utemeljeno na ljudskoj naravi. Ono nam pomaže da razotkrijemo i razvijemo unutarnje sposobnosti te nas usavršava, omogućavajući nam da postignemo »ono stanje prema kojem je ljudska narav usmjerena i prema kojem teži; to je sistematična upotreba, poboljšanje i kombinacija onih moći koje su nama karakteristične... to je ispravna raspodjela raznih moći duše, svake na svojem mjestu, subordinacija ili podlaganje onih nižih i ujedinjenje svih u jednu cjelinu $\ll^{8}$.

\footnotetext{
${ }^{4}$ Bitno je napomenuti da iako Newman u svojoj obrazovnoj teoriji češće govori o intelektualnom nego moralnom savršenstvu, on intelektualno savršenstvo nije nikada gledao kao nešto što treba kultivirati na štetu drugih vrlina. Dapače, promatrao ga je kao jednu u nizu međusobno povezanih i ovisnih vrlina koje bi trebale pomoći čovjeku ispuniti sve svoje potencijale kao ljudska osoba.

${ }^{5}$ Najveći dio Newmanove obrazovne teorije nalazimo u djelu Ideja sveučilišta koje je nastalo iz niza predavanja održanih u Irskoj prilikom otvorenja katoličkog sveučilišta kojem je ujedno bio prvi rektor. Ovo djelo s Logikom pristanka i Razvojem kršćanske doktrine spada među Newmanova najutjecajnija djela. Zanimljivo je primijetiti da on nije utjecao samo na teoretsku nego i na praktičnu stranu pitanja jer danas u svijetu postoji nekoliko sveučilišta i koledža koji su osnovani na principima koje je Newman iznio u prethodno spomenutom djelu. Među njima spominjemo Newman sveučilište u Birminghamu, u Engleskoj, Newman College u Corku u Irskoj i Newman sveučilište u Wichiti u SAD-u (usp. M. POLJAK, Newmanovo shvaćanje sveučilišta kao mjesta intelektualne formacije, 128.).

${ }^{6} \mathrm{~J}$. H. NEWMAN, The Idea of a University, Oxford, 1976., 104.

${ }^{7}$ J. H. NEWMAN, An Essay in Aid of Grammar of Assent, 225.-226.

${ }^{8}$ J. H. NEWMAN, Historical Sketches, II, New York, 1903., 165.
} 
Ovdje je važno primijetiti da se razvoj i napredovanje na intelektualnom području može postići samo preko ispravne upotrebe našeg uma, a za Newmana to znači da razvoj mora biti vođen naravnim zakonima iz kojih proizlazi. ${ }^{9}$ Zato on kao jedan od glavnih ciljeva obrazovanja postavlja ne samo obogaćenje i usavršavanje uma novim spoznajama nego i zaštitu od pogrešnog razvoja. Ispravan razvitak osigurava nam da svoj um koristimo ispravno i za svrhu za koju je stvoren - a to je spoznaja istine - stoga je potreba dobroga obrazovanja dodatno pojačana. Naime, na činjenicu da ćemo se razvijati ne možemo utjecati, no hoće li taj razvoj ići u dobrom smjeru ili ne uvelike ovisi o nama. Promotrimo li samo skromne početke ljudskog spoznajnog života, jasno je kako iz toga mogu proizaći ne samo dobre nego i loše stvari. Preko vanjskih osjetila mi, takoreći »upijamo « izvanjski svijet te još nismo sposobni sve ispravno sortirati. No, malo po malo kako se razvijamo počinjemo razlikovati predmete, međusobno ih povezivati te na kraju imenovati. Ono što je na početku bilo mutno i nejasno, postupno postaje jasnije i razumljivije, te stvari s kojima se susrećemo počinjemo klasificirati, analizirati i sistematizirati, dobivajući tako jednu pregledniju sliku onoga što je pred nama. Newman ističe da nam je ovo formiranje jedne obuhvatnije slike svijeta $\gg$ toliko naravno... da je gotovo spontano; i mi smo nestrpljivi kada ga ne možemo koristiti, i stoga ne čekamo uvijek posjedovanje sredstava [koja će nam omogućiti ispravnu formaciju], nego često podnosimo nedovoljne ili apsurdne poglede ili interpretacije onoga što susretnemo ${ }^{10}$ radije negoli da nemamo nikakav općenit pogled na stvar.

Činjenica da čovjek po svojoj naravi ima potrebu sistematizacije i povezivanja stvari, a ujedno znajući da tu možemo počiniti velike pogreške jako lako, Newman nudi obrazovanje kao jedno od rješenja problema. Drugim riječima, jedan od načina kako spomenute pogreške možemo izbjeći jest kvalitetno i sveobuhvatno obrazovanje, koje bi na višim razinama sveučilište trebalo ponuditi. Ono bi trebalo biti mjesto gdje studenti imaju priliku ne samo usvojiti složenije spoznaje nego bi im također trebalo dati ispravnu metodu rada, širi pogled na svijet te ih osposobiti za samostalno pronalaženje istine - pravog objekta naše razumske spoznaje koji usavršava intelekt, a preko usavršavanja intelekta također usavršava naš cijeli život. Stoga je spoznaja istine ne samo neko dobro za nas, nego nužno dobro za nas kao racionalna bića. Usavršavanje ljudskih intelektualnih sposobnosti tako postaje iznimno važno bez obzira može li ono poslužiti u svrhe materijalnog probitka, komfora, užitka ili sigurnosti.

\footnotetext{
${ }^{9}$ Za Newmana ovo je jedna od glavnih oznaka ispravnog razvoja, stoga promjena koja se događa i koja je protivna naravi bića i zakonima koji su njega zapisani nije na dobrobit toga bića (Usp. J. H. NEWMAN, Development of Christian Doctrine, New York, 1949., 177.).

${ }^{10} \mathrm{~J}$. H. NEWMAN, The Idea of a University, 75.
} 
Kada govorimo o korisnosti obrazovanja, Newman je bio zagovornikom teorije da je posjedovanje znanja, posebno onog povezanog s duhovnim dobrima, određeno bogatstvo u sebi bez obzira na neku praktičnu korist koju možemo imati od toga. Samim time on se suprotstavljao utilitarističkom shvaćanju obrazovanja koje je u 19. st. stjecalo sve više zagovornika, te koje je težilo što ranijem usmjerenju prema uskim specijalizacijama koje bi proizvele stručnjake koji bi radili za dobrobit i unapređenje društva i države. U svome djelu Ideja sveučilišta Newman ulazi u raspravu sa zastupnicima ove teorije, te prije svega nudi svoje razloge važnosti humanističke naobrazbe koju vidi kao dobro ne samo za pojedinca nego i za društvo u kojem se on nalazi. ${ }^{11}$

\section{Newman i utilitaristički pristup obrazovanju}

Na samom početku objasnimo što se točno podrazumijeva pod sintagmom »utilitaristički pristup obrazovanju «, te ćemo se za to poslužiti Newmanovim razumijevanjem istoga. U vrijeme kada je Newman pisao Ideju sveučilišta, u Engleskoj su zagovornici obrazovnog sustava temeljenog na uskoj specijalizaciji postajali sve glasniji. Predlagali su drastične reforme sveučilišnog obrazovanja koje je u nekim prestižnim ustanovama - kao Oxford - još uvijek bilo pod izrazitim utjecajem humanističkog ideala gdje se veliki naglasak stavljao na studiranje predmeta koji su se u Engleskoj 19. st. smatrali zastarjelima i nepotrebnima. Tako su se prvi na udaru našli teologija i klasični jezici. S jedne strane, izrazita liberalistička struja dovodila je u pitanje objektivnost i valjanost teologije, dok su, s druge strane, veliki napredak u prirodnim, tehnološkim znanostima i medicini te njihova primjena na potrebe svakidašnjeg života doveli u pitanje korisnosti studija kao što su klasični jezici. Suočen s ovakvim društvenim kretanjima na početku formiranja novog sveučilišta,

\footnotetext{
${ }^{11}$ Ovdje možemo kratko napomenuti kako je Newman smatrao da je sveučilište, za razliku od suvremenog poimanja sveučilišta, prije svega obrazovna, a ne istraživačka institucija, čime ga je htio odvojiti od raznih znanstvenih instituta i društava koji su, u to vrijeme, bili rasprostranjeni u Engleskoj. Newman je shvaćao važnost instituta i raznih društava zbog njihovog direktnog doprinosa otkrivanja novih znanstvenih spoznaja, no zalagao se za to da se poučavanje i istraživanje kao dvije različite djelatnosti trebaju jasno odvojiti. Tako u Ideji sveučilišta Newman kaže da su istraživanje $\mathrm{i} \gg$ poučavanje dvije različite funkcije; one su također dva različita talenta koja se često ne mogu naći ujedinjena u jednoj osobi. Onaj... tko provodi svoje dane prenoseći svoje postojeće znanje svim pridošlicama najvjerojatnije neće imati ni slobodnog vremena ni energije da stječe novo. Ljudi su oduvijek potragu za istinom povezivali s izolacijom i tišinom. Najveći mislioci bili su previše usredotočeni na svoj objekt da bi dopuštali prekide; oni su bili ljudi... sa specifičnim navikama i uglavnom su izbjegavali predavaonice i javne škole $\ll($ Isto, 8.).
} 
Newman u svome djelu pokušava opravdati postojanje i važnost humanističkog obrazovanja $^{12}$.

Po svom ustaljenom običaju, Newman u svojoj retorici koristi temeljni princip utilitarizma - princip korisnosti - te ga okreće u vlastitu prednost. Tako obranu humanističke naobrazbe Newman temelji na načelu da je dobro, bez obzira o kojoj vrsti dobra govorili, uvijek korisno. ${ }^{13}$ Budući da znanje bilo koje vrste predstavlja neko dobro, onda je to znanje i nešto što je korisno za nas. Iščitavanjem do sada napisanoga, netko bi mogao zaključiti da se Newman ne razlikuje previše od utilitarista, jer zajedno s njima korist stavlja u temelj obrazovnog sustava. Situacija, međutim, nije tako jednostrana koliko se na prvu može činiti te se lako može objasniti uočavanjem prioriteta što ga Newman daje dobru pred korisnošću. Prema njemu čovjek treba težiti za znanjem zato što znanje predstavlja određeno dobro za čovjeka, dok je korisnost sekundarna posljedica koja proizlazi iz dobra kao takvog. Kod utilitarista poredak je obrnut, kod njih trebamo težiti za znanjem ne zato što je neko dobro, nego zato što je korisno, a samim time što je korisno, ono je ujedno i dobro. Vidimo dakle, da je kod Newmana dobro ono koje ima primat nad korisnim te korisno proizlazi iz dobra. Kod utilitarista korisno ima primat nad dobrim te utemeljuje to dobro.

Dodatno pojašnjenje njegovog shvaćanja odnosa između dobra i korisnog vidimo u citatu gdje kaže da »iako ono što je korisno, nije uvijek dobro, dobro je uvijek korisno $\ll{ }^{14}$. Newman dalje nastavlja s pojašnjenjem zašto je formacija koju naš razum prima preko humanističkog obrazovanja ne samo nešto dobro za nas nego i nešto korisno, te kaže: »Stoga ako je razum tako izvrstan dio nas i njegova kultivacija tako izvrsna, onda nije samo lijep, savršen, pohvalan i plemenit u sebi, nego $\mathrm{u}$ istinitom i uzvišenom značenju mora biti i koristan onome koji ga posjeduje $\mathrm{i}$ svima oko njega; koristan ne u nekom niskom, mehaničkom, trgovačkom smislu,

${ }^{12}$ Sintagma 'humanističko obrazovanje' označava prijevod Newmanova pojma liberal education. Humanističko obrazovanje u ovom kontekstu ima šire značenje od onog koje mu se često pripisuje. Ono se ne može svesti samo na poznavanje humanističkih znanosti kao takvih, nego prije svega označava onu vrstu obrazovanja koje omogućuje osobi sposobnost logičkog promišljanja, istančanost ukusa, uvažavanje duhovnih ideala, formiranje sveobuhvatne slike svijeta, pronalaženje temeljnih principa stvarnosti. Humanističke znanosti čine plodno tlo za razvijanje ovih sposobnosti, no pasivno poznavanje njihovih činjenica neće nam dati spomenute dispozicije nego samo materijal koji moramo kroz aktivno promišljanje oblikovati. Jednostavnije rečeno, obrazovanje kako ga je Newman zamislio nužno u sebi uključuje humanističke znanosti, no da bi bilo idealno obrazovanje, ono mora omogućiti osobi ne samo poznavanje filozofskih ili npr. teoloških sustava, nego također razumijevanje njihovih temeljnih principa te prepoznavanje i primjenu istih u svakodnevnom životu i usporedbu sa spoznajama i principima koje već posjedujemo.

${ }^{13}$ Usp. isto, 144.-145.

${ }^{14}$ Isto. 
nego kao ono što širi dobro, ili kao blagoslov, ili dar, ili moć, ili blago, prvo samom vlasniku, i preko njega cijelom svijetu. Stoga kažem, ako je humanističko obrazovanje dobro, mora nužno biti i korisno $\ll^{15}$.

Vidimo da Newman ovdje proširuje značenje riječi $\gg k o r i s n o \ll$, te sve što nam pomaže pri usavršavanju nas samih nije samo dobro nego je samim time i korisno za nas. Stoga posjedovanje bilo kojeg znanja, premda to znanje neće polučiti nekim materijalnim dobitkom ili interesom, pomaže nam pri postizanju višeg stupnja intelektualne izvrsnosti, a samim je time korisno za nas. Kada je riječ o humanističkom obrazovanju, Newman ga je neprestano zagovarao zato što je znao da ono ne samo da oplemenjuje ljudski duh spoznajama koje ga uzdižu iznad čisto materijalnog svijeta nego nam također pomaže pri formaciji samoga uma, uči nas misliti prema određenom redu, povezivati premise u zaključak, tražiti osnovne principe stvarnosti i stvarati jednu povezanu i koherentnu sliku svijeta koja nam omogućava sortiranje životnih prioriteta.

Newman je bio protiv isključivo specijaliziranog obrazovanja koje u sebi nije uključivalo poznavanje šire humanističke kulture, zato što ga je vidio kao ono što nam nudi fragmentiranu sliku stvarnosti koja je proturječna duhu sinteze i sveobuhvatnosti kojem ljudski um po svojoj naravi teži. Humanističke nam znanosti mogu ponuditi tu sliku zato što se one dotiču pitanja i problema koji su u temelju same stvarnosti. Pogledajmo samo filozofiju koja čovjeku nudi svojevrsnu sliku svijeta i koja u njemu razvija one duhovne potencijale koji su potrebni svakoj osobi koja se želi izgraditi u najbolju moguću verziju sebe same. Važno je napomenuti da se onaj pojedinac koji preko svoga obrazovanja ne dobije ovu opću sliku neće pomiriti s tim stanjem, nego će je na temelju djelomičnih spoznaja koje posjeduje pokušati sam stvoriti. Što su njegove spoznaje ograničenije, više specijalizirane i fragmentirane, to će njegova slika svijeta biti udaljenija od istine te će mu učiniti isto što $\mathrm{i}$ svaka druga zabluda - nanijet će mu štetu. Zato je, uz obrazovanje koje nudi usavršavanje na jednom području od kojeg imamo materijalnu korist, potrebno nadodati i bogato humanističko obrazovanje koje će naše specijalističko znanje staviti u pravi kontekst i na pravo mjesto. U protivnom će nam se dogoditi upravo ono što se dogodilo tolikim specijalistima, a to je da ćemo principe i zaključke svoje znanosti pretvoriti u ključeve za interpretaciju cjelokupne stvarnosti. Stoga vidimo da jedno šire i obuhvatnije obrazovanje omogućava ne samo da imamo više informacija nego nas također štiti od nedopuštenih generalizacija. ${ }^{16}$

${ }^{15}$ Isto, 144.

${ }^{16}$ Kritizirajući negativne posljedice uske specijalizacije, Newman opisuje osobu koja ne znajući ograničenja svoje znanosti i svoje spoznaje, pokušava cjelokupnu stvarnost objasniti jednom metodom i principima svoje struke. Tako on »postaje, što se obično zove, čovjek jedne ideje; što zapravo znači 
Bitno je napomenuti da potreba za stvaranjem jedne sveobuhvatne slike stvarnosti proizlazi ne samo iz naravi ljudskog uma nego i iz svijeta kao jednog od objekata naše spoznaje koji je sam u sebi složena cjelina sastavljena od mnoštva međusobno povezanih dijelova. Svaki od tih dijelova uzet sam za sebe neovisno o cjelini kojoj pripada ne može ponuditi cjelokupnu istinu o sebi, jer on čini dio jedne veće cjeline koja mu uz identitet daje ujedno i pripadajuće mjesto u sustavu. Stvarnost ovako strukturirana i sveučilište koje se bavi proučavanjem te stvarnosti ima zadaću ponuditi svojim studentima upravo ovu ideju složenosti sustava koji proučavaju, te se znanosti koje čine jedno sveučilište trebaju međusobno konzultirati, nadopunjavati, limitirati i ispravljati. ${ }^{17}$ Kvalitetna sveučilišna naobrazba trebala bi nam, dakle, dati upravo ovu sveobuhvatniju sliku, zahvaljujući kojoj smo sposobni vidjeti mnoge stvari kao dijelove jedne cjeline, te bismo ih mogli ispravno smjestiti s obzirom na mjesto koje posjeduju u univerzalnom sustavu. ${ }^{18}$

No, da bi sveučilišni student mogao dobiti ovaj povezan i smislen pogled na svijet, potrebno je na sveučilištu njegovati ne puko usvajanje znanja koje je često pasivno, nego je potrebno aktivno uključiti razumske potencijale da bi shvatili, prisvojili i povezali nove ideje. To označava njegovanje formativne moći koja omogućava da stvaramo red, da takoreći probavimo ono što smo primili te da to povežemo s onim što već posjedujemo, da analiziramo, sistematiziramo i utemeljujemo novo na starim bazama koje su već stvorene i prokušane.

čovjek jedne znanosti i pogleda koji je djelomično istinit, ali podređen, djelomično pogrešan, što je zapravo sve što može proizaći iz nečega tako polovičnog. Tako dobivamo principe korisnosti, kombinacije, progresa, filantropije ili u materijalnim znanostima, komparativne anatomije... elektrike uzdignute na razinu vodećih ideja i ključeva, ako ne cjelokupnoga znanja, onda barem mnogo više stvari negoli im pripada - principi, svaki od njih istiniti do određene granice, ali pretvoren $u$ pogrešku ... zato što je preuveličan (Isto, 76.).

${ }^{17}$ Usp. M. POLJAK, Newmanovo shvaćanje sveučilišta kao mjesta intelektualne formacije, 136.-137.

${ }^{18}$ Newman upravo ovakvo shvaćanje svijeta koristi kao jedan od argumenata kojima želi pokazati nužnost postojanja studija teologije na sveučilištu. Naime, kada je riječ o važnosti teološkog studija za Newmana, spomenimo samo činjenicu da je jedan od osnovnih motiva u djelu Ideja sveučilišta dokazivanje važnosti teologije za sveučilište. Newman polazi od toga da sam naziv sve-učilište upućuje na mjesto koje je otvoreno svim znanostima, te se teologija kao takva mora među njima nalaziti. Razlozi su za to višestruki, no smatramo da su sljedeća dva najvažnija: prvo, ona se bavi spoznajama koje su za čovjeka od životne važnosti - a to su spoznaje u vezi s Bogom i njegovim odnosom s čovjekom. Promatrano iz ove perspektive, jasno je zašto teologija ima privilegirano mjesto među svim drugim znanostima kao ona koja promatra najuzvišenije istine o kojima ovisi čovjekov život i spasenje. Drugi je razlog povezan s njegovim shvaćanjem svijeta kao cjeline koja se sastoji od dijelova, te ljudskoga znanja kao slike te cjeline koja se također sastoji od međusobno povezanih i ovisnih dijelova. Svaka znanost predstavlja jedan od tih dijelova, te ako izostane jedan, onda će integritet cjeline biti narušen, te što je važniji dio koji nedostaje, to će slika cjeline kao takva biti deformiranija. 
Prema Newmanu, rezultat je svega ovoga formacija uma koja nam omogućava da uskladimo novo sa starim, da vidimo osnovne principe koji upravljaju danom situacijom ili predmetom, da ispravno deduciramo zaključke iz premisa, da se ne žurimo te da imamo strpljenja sa složenim stvarnostima koje se postupno i sporo rješavaju. Jasno je da tamo gdje postoji ovakva moć razmišljanja, objekti proučavanja postaju nešto duboko, zanimljivo, intrigantno, a popularne publikacije i govornici dana nisu više nepogrešivi autoriteti.

Uz navedeni razlog Newmanova protivljenja isključivom utilitarističkom i specijalističkom obrazovanju, postoji još jedan koji je još temeljniji. Newman je, naime, smatrao da ona vrsta obrazovanja koja se temelji na utilitarizmu u sebi sadrži pogrešnu sliku čovjeka i njegovog finalnog dobra. Prema Newmanu, ovu vrstu obrazovanja čovjek promatra samo s materijalnog gledišta, te se brine o tome da nakon studija nađe posao koji će mu omogućiti financijsku sigurnost. Osim što sam pojedinac ima konkretnu materijalnu korist od svog obrazovanja, to također imaju i znanost i društvo. Znanost zato što napreduje preko svojih stručnjaka, a društvo zato što napreduje preko znanstvenih dostignuća. No, iako su sve spomenute stvari važne i dobre, ljudski se život ne može svesti na njih, smisao se ljudskoga života ne može u njima ispuniti. Osim što je čovjek materijalno biće s materijalnom potrebama, on u sebi ima i duhovni element koji se materijalnim postignućima ne može zadovoljiti. Čovjeku je potreban kruh kao jedan od temeljnih uvjeta njegovog života, no naglasak ovdje nije na riječi $\gg$ uvjet $\ll$, nego na riječima $\gg$ jedan od $\ll$. To zapravo znači da je kruh nužan, ali sam za sebe nije dovoljan. U svojoj slici čovjeka Newman polazi od toga da je on biće koje u sebi kao svoj sastavni element ima i dušu kao princip života višeg reda. Tako, osim što se moramo brinuti za svoje tijelo, moramo se pobrinuti i za dušu, te nam sveučilišno obrazovanje obogaćeno humanističkim znanjem nudi upravo to.

Newmanu je jasno da čovjek mora završiti svoju struku, te da mu obrazovanje između ostaloga treba ponuditi znanje i vještine koje će mu omogućiti da može živjeti od svoga posla. No, obrazovanje se ne može svesti isključivo na to, nego ono također treba potaknuti pojedinca da teži za posjedovanjem znanja ne samo onoga koje je u materijalnom svijetu korisno, nego u njemu treba njegovati i ljubav prema mudrosti koja će ga uputiti u spoznaje višega reda stvarnosti. Humanističke znanosti kao takve nude određeno znanje koje oplemenjuje ljudski um i duh na način na koji to druge znanosti ne mogu učiniti, te baveći se humanističkim znanostima, mi obogaćujemo svoj život na način na koji to ne bismo mogli drukčije učiniti. Stoga Newman ističe da je spreman zalagati se za postojanje nekih spoznaja koje su vrijedne posjedovanja ne zbog onoga što one mogu za nas učiniti, nego zbog toga što 
jesu. ${ }^{19}$ Spoznaja smisla i važnosti ljepote, spoznaja vrijednosti dobrote, što je istina, kako do nje doći itd., sve su to spoznaje koje obogaćuju naš život te nas čine boljim i plemenitijim ljudima iako nam djelovanje na temelju njih nije uvijek od materijalne, ovozemaljske koristi. U Ideji sveučilišta Newman oštro kritizira protivnike ovog stava, govoreći da ga pojedinci ne mogu lako dopustiti: $\gg$ Oni inzistiraju da obrazovanje mora biti određeno prema nekom pojedinačnom i uskom cilju, i da treba rezultirati nekim konkretnim radom koji se može vagati i mjeriti. Oni raspravljaju kao da sve stvari, kao i svaka osoba, ima svoju cijenu, i da tamo gdje je velik ulog imaju pravo tražiti nešto zauzvrat. Na to misle kada zovu obrazovanje i poučavanje korisnim i korisnost postane njihova krilatica. $S$ temeljnim principom ove naravi, oni naravno postavljaju pitanje što sveučilište može dati s obzirom na svoje troškove, koja je prava cijena tržišnog artikla koji se zove humanističko obrazovanje, u slučaju da nas ono ne uči kako poboljšati svoje tvornice, zemlju ili ekonomiju... Ništa ih ne zadovoljava, nego da se sveučilište postavi na temeljima filozofije utilitarizma, filozofije koju, oni misle, samo treba izreći da bi je svi prihvatili. ${ }^{20}$

Za one koji žele visoko obrazovanje svesti samo na znanosti korisnu u materijalnom ili ekonomskom smislu, te navesti studente na usku specijalizaciju, Newman ističe riječi E. Coplestona koji kaže da podjela rada vodi do usavršavanja svake vještine, do bogatstva naroda, te općeg dobra države. Što je pojedinac usmjereniji na jedan rad, to će više i brže u njemu postići savršenstvo. No, dok on tako pomaže svome narodu i znanosti, on sam gubi jer sužava svoje djelovanje na jedno područje i samo se u njemu razvija dok u drugima ostaje zakržljao: »Proporcionalno tome kako se njegova sfera djelovanja sužava, njegove se mentalne moći i navike kontraktiraju i on počinje sličiti podređenom dijelu neke moćne mašinerije koji je koristan na svom mjestu, ali nebitan i bezvrijedan izvan nje. ${ }^{21}$ Drugim riječima, nema sumnje da znanosti i u određenom smislu društvo preko uske i stroge specijalizacije napreduju, ali dok oni napreduju, sam znanstvenik nazaduje. Društvo kao takvo treba od pojedinaca koji ga čine nešto dodatno osim njihove specijalističke sposobnosti, i ako zanemarimo humanističke znanosti koje nam mogu pomoći u ovom uzvišenijem dijelu našeg života, onda će eventualno i samo društvo patiti zbog toga.

\section{Sveučilište i moralni razvoj}

Nakon što smo vidjeli prednosti koje humanističko obrazovanje nudi pri intelektualnoj formaciji osobe, preostaje nam pogledati kako ono utječe na oblikovanje moralnog karaktera pojedinca. Sveučilište je, kako smo već prije spomenuli, odgoj-

\footnotetext{
${ }^{19}$ Usp. isto, 98.

${ }^{20}$ Isto, 135.-136.

${ }^{21}$ Isto, 147.
} 
no-obrazovna ustanova, te osim što nas formira na intelektualnoj razini preko raznih spoznaja koje u njemu stječemo, ono također pomaže odgojiti pojedinca poticanjem razvoja moralnih kreposti koje su nam nužne ne samo u poslovnom životu nego i u osobnom i društvenom. Iz ovoga dodatno vidimo da jedno sveobuhvatno sveučilišno obrazovanje treba, uz uske specijalizacije koje vode prema stjecanju znanja i vještina za ostvarenje poslovnog uspjeha, njegovati i humanistički ideal visokoobrazovanog čovjeka, koji uz izvrsne intelektualne sposobnosti posjeduje i plemenito ponašanje.

Kada je riječ o Newmanu, on je rano uočio potrebu da svoje studente potakne ne samo na intelektualnu nego i na moralnu izvrsnost, a to je značilo da uz teoretsko objašnjenje moralnih vrijednosti, treba ići i praktični, konkretni poticaj od obrazovne ustanove da se te vrijednosti implementiraju u svakodnevnom životu. Newman je smatrao da su sami profesori oni koji svojim uzornim i primjerenim ponašanjem trebaju dati poticaj u pravom smjeru, te da se trebaju brinuti ne samo za intelektualnu stranu svojih učenika nego i za moralnu. ${ }^{22}$ Newman je bio čvrsto uvjeren da je osobni utjecaj koji profesor može imati na svoje studente jako bitan i snažan, te da nastavnici trebaju biti oni koji utjelovljuju ideale kojima istovremeno poučavaju svoje studente.

Vrhunac ili ideal humanističkog obrazovanja, kako u intelektualnom, tako i u moralnom smislu, Newman nalazi u liku džentlmena koji zajedno s istančanim spoznajnim moćima, te bogatom kulturom, posjeduje ujedno i profinjen, elegantan način ophođenja s drugima. Zasigurno, jedan od najpoznatijih i najcitiranijih dijelova Ideje sveučilišta upravo je Newmanov opis džentlmena koji ćemo ovdje djelomično navesti: »Stoga je gotovo definicija džentlmena da je on onaj koji nikada ne nanosi bol... on je pažljiv prema svima u svojem društvu, nježan prema stidljivima, pažljiv prema distanciranima, milosrdan prema apsurdnima; uvijek je svjestan s kim priča, čuva se neprikladnih aluzija ili tema koje mogu biti iritantne, ne nameće se u razgovoru i nije naporan. Ne priča o sebi osim ako na to nije prisiljen... ne sluša klevetanje ni ogovaranje, i sve interpretira nabolje. U raspravama nikada nije zloban ili sitničav, nikada ne uzima nepoštenu prednost i ne insinuira zlo koje sam ne bi rekao naglas. Razborito slijedi staru izreku da se trebamo odnositi prema neprijatelju kao da će nam jednoga dana biti prijatelj... Strpljiv je, podnosi sve na filozofskim principima... prihvaća bol zato što je neizbježna i smrt zato što je to njegova sudbina. Može biti u pravu ili pogriješiti, ali je previše zdravorazuman da bi bio nepošten. Koliko je jednostavan toliko je silan, kratak je koliko je odlučan. On ulazi u um svojih protivnika i promišlja o greškama. Poznaje slabost i snagu ljudskoga razuma, njegovu širinu i ograničenja. Ako nije vjernik, previše je dubokouman i širokovidan

${ }^{22}$ Usp. J. H. NEWMAN, Historical Sketches, III, Milton Keynes, 2007., 74.-75. 
da bi ismijavao religiju ili da bi djelovao protiv nje... previše je pametan da bi bio dogmatičan ili fanatičan u svojoj nevjeri $\ll^{23}$. Ovo su samo neke od karakteristika čovjeka koji je u sebi utjelovio ideal humanističkog obrazovanja.

Jedna od velikih prednosti Newmanove obrazovne teorije upravo je u tome što je on neprestano isticao važnost stavljanja čovjeka kao cjelovite osobe u središte obrazovnog sustava čime se potiče razvoj ne samo našeg intelektualnog potencijala nego i svih drugih potencijala koji spadaju pod domenu formalnog obrazovanja. Odmah napominjemo da Newman nije smatrao da sveučilište, bez obzira koliko dobro, uspješno i kvalitetno bilo, može izgraditi čovjeka na svim razinama njegovog bića. Postoji cijeli niz spoznaja, vještina i kreposti koje mi stječemo van sveučilišta, no, ono što nam kvalitetna sveučilišna naobrazba može ponuditi jest usavršavanje određenih intelektualnih i moralnih potencijala koji će nam uvelike obogatiti život. $^{24}$

\section{Zaključak}

Vratimo se na prvo poglavlje i ponovno pođimo od toga da je čovjek po svojoj naravi biće razvoja. Krenuvši od ovoga, jasno nam je koliko je kvalitetno obrazovanje za čovjeka važno, posebno uzevši u obzir činjenicu da odgojno-obrazovni sustav služi usavršavanju dviju temeljnih ljudskih moći: razuma i volje. Time što smo rekli da je čovjek po svojoj naravi ili biti biće razvoja, mi zapravo ističemo da čovjek po tom pitanju nema izbora, dok je živ on će se razvijati. No, kada je riječ u kojem će smjeru taj razvoj ići, te koju će granicu dosegnuti, to uvelike ovisi o raznim faktorima kao što su talent, materijalne i društvene mogućnosti, motivacija, interes, podrška itd. Što se više ovih faktora poklopi, to će razvoj biti lakši i uspješniji. Iako na neke od spomenutih elemenata ne možemo utjecati (npr. na talent s kojim smo rođeni), postoje oni koji uvelike ovise o nama, te smo stoga za njih i osobno odgovorni. Motivacija, rad, disciplina, spremnost na žrtvu samo su neki od njih.

\footnotetext{
${ }^{23}$ J. H. NEWMAN, The Idea of a University, 179.-180.

${ }^{24}$ Kada je riječ o ograničenosti sveučilišnog obrazovanja, Newman ju je posebno isticao na području vjere, te prilikom opisa džentlmena koji smo prethodno vidjeli, on naglašava da je ovo ideal koji svijet kao takav može pred nas staviti. Taj je ideal dobar u sebi i sasvim prikladan na svome mjestu, no on nas neće pripremiti ni osposobiti za junačke pothvate koji se od nas u životu ponekad traže. Sveučilišna naobrazba predstavlja samo jedan dio našeg intelektualnog i moralnog razvoja, te je na svome mjestu važna i nužna, no ona nas neće dovesti do visokih vrhunaca za koje je čovjek po svojoj naravi sposoban. Za takvo je što potrebno mnogo više. Razlog zbog kojeg je on ovo isticao jest iskustvo koje je imao sa svojim suvremenicima koji su smatrali da obrazovni sustav, bez obzira o kojoj vrsti govorimo, može čovjeku ponuditi odgovore na sva pitanja i rješenje svih problema. Newman kao vjernik, kao svećenik, kao čovjek, znao je da nam je za to potrebno mnogo više.
} 
Kada je riječ o obrazovanju, smatramo da ono pretpostavlja ne samo uložen napor profesora već i studenata. Nastavni proces u sebi sadrži dva temeljna sudionika, te ako bilo koji od njih zakaže, obrazovanje neće biti uspješno. Kada je riječ o današnjem obrazovanju, ono je donekle pod utjecajem utilitarizma 19. st. te glasovi koji zastupaju reorganizaciju obrazovnog sustava koji bi trebao ići u smjeru rane i uske specijalizacije postaju sve jači i jači. Teži se tome da se stvore mladi, sposobni, radišni ljudi koji će se specijalizirati u onim strukama koje su od praktične, materijalne koristi kako njima samima, tako i cjelokupnom društvu. Tako se često može čuti pitanje: čemu studij književnosti, klasičnih jezika, filozofije, teologije, povijesti umjetnosti itd., kad od toga nema konkretne zarade? Oni koji upišu spomenute studije, nerijetko se susreću s pitanjem: Koja ti je korist od toga? Ili, što ćeš raditi nakon studija? Ovdje već vidimo da se obrazovanje prije svega promatra kao priprema za neku konkretnu karijeru koja sa sobom nosi dobar posao i solidnu plaću. Budući da nam obrazovanje služi samo za to, onda što se ranije odluče za neki takav studij i što prije započnu proces specijalizacije, to bolje za njih.

Kao što smo vidjeli kod Newmana, specijalizacija, iako nužna sastavnica obrazovanja, ne može biti jedini oblik obrazovanja iz razloga što obrazovni sustav koji se isključivo temelji na uskim specijalizacijama i pripremama za karijeru, iako predstavlja određenu dobrobit za samu znanost i društvo, nije u potpunosti dobar za samog pojedinca. Čovjek je mnogo više od radnika ili profesionalca, njegov se život ne sastoji samo od poslovnog dijela nego i od osobnog, stoga bi obrazovni sustav trebao težiti tome da pojedincu pomogne ne samo da nakon školovanja osigura dobar posao koji će uspješno obavljati, nego mu također treba pomoći u stvaranju jedne sveobuhvatnije slike svijeta, treba ga naučiti ispravno razmišljati, analizirati i donositi zaključke. To su samo neke od prednosti koje može dobiti od kvalitetnog sveučilišnog obrazovanja, a koje će mu pomoći u njegovom svakodnevnom životu. No, osim što obrazovanje utječe na samog pojedinca, ono također predstavlja jedan od načina kako prenosimo i transformiramo našu kulturu. Ono u sebi nosi poruku o našim vrijednostima, prioritetima i načinu na koji strukturiramo svijet, stoga preko njega ne samo da pomažemo pri usavršavanju pojedinca, nego također pomažemo duhovnom usavršavanju i očuvanju društva i kulture kojoj pripadamo.

U svome djelu Beauty for Truth's sake S. Caldeccot ističe živu potrebu kvalitetnog visokog obrazovanja posebno $u$ današnje vrijeme $u$ kojem je um studenta pretrpan raznim informacijama koje dolaze sa svih strana, te gotovo da nemamo vremena stati i promisliti o svemu što čujemo, vidimo, osjetimo: »Učitelji obično kažu da suvremeni studenti ne znaju misliti. To je nešto što su uvijek govorili, no u današnje vrijeme kao da je sve usmjereno prema tome da ne mislimo vlastitom glavom. Tišinu je teško naći, zabave prodiru u sve, i pritisak da konzumiramo i odbacimo [konzumirano] gotovo je neodoljiv... nije ni čudno da studenti koji dođu na sveuči- 
lište ne očekuju ništa drugo nego komad papira koji će im omogućiti da se zaposle. Sama ideja da bi tamo mogli rasti kao ljudska bića i da mogu postati nešto više nego što jesu, sasvim im je strana. Oni očekuju trenutne odgovore, a nemaju dubokih pitanja. $\ll^{25}$ Sličnu opasku nalazimo i kod D. Sayers koja kaže da je svijet studenta preplavljen riječima za koje oni ne znaju što znače, »ne znaju kako ih otkloniti ili otupiti njihovu oštricu ili ih odbaciti; oni su plijen za riječi u svojim emocijama umjesto da budu njihovi vladari u svojim umovima $\ll{ }^{26}$. Sveučilište bi stoga trebalo biti mjesto koje će studente pripremiti na svijet ideja u kojem se već nalaze. Iz dana u dan susrećemo se s raznim stavovima, principima, pogledima na život, od kojih su neki u direktnoj suprotnosti s našim. Smatramo da bi obrazovni sustav trebao pružiti alat koji će nam omogućiti snalaženje u ovom svijetu, te obranu ideala koje držimo. Prirodne, medicinske, tehnološke znanosti, ne mogu nam to pružiti, to je uvijek bila zadaća humanističkih znanosti, te izbaciti njih iz obrazovnog sustava znači onemogućiti velikom dijelu populacije da misli vlastitom glavom.

Ako usporedimo današnji obrazovni ideal s idealom iz prošlosti, vidimo da je došlo do određenog oštrog pomaka. Svrha znanosti i obrazovanja više nije da se stekne mudrost, upozna svijet i usavrši samoga sebe, nego je naglasak gotovo isključivo stavljen na korisnost znanja u svrhu praktičnih potreba čovjekova svakodnevnog života. No, moramo znati da svrha obrazovanja nije samo to da se prenesu informacije, niti da se treniraju budući radnici ili menadžeri, već $i$ to da se nauči sposobnost mišljenja, razlučivanja, govora, pisanja, te da se uoče unutarnji principi koji upravljaju stvarima. Ovakvo će što ne samo pripremiti studente za budući posao već im i pomoći u životu kao takvom.

\footnotetext{
${ }^{25}$ S. CALDECOTT, Beauty fo Truth's Sake, Grand Rapids, 2009., 20.

${ }^{26}$ D. SAYERS, The Lost Tools of Learning, London, 1973., 118.
} 


\section{THE ROLE OF THE UNIVERSITY IN THE INTELLECTUAL AND MORAL DEVELOPMENT OF MAN}

\section{Maja POLJAK*}

Summary: Education belongs among the most important means for the development of human intellectual potential. Whether formal or informal, education has always played an important role both in the life of the individual and in the life of the community. In the paper before us, the author discusses some of the basic principles of educational theory of the English thinker J. H. Newman. The first chapter of the paper discusses man seen as a being of development who needs certain means to help him reach his intellectual excellence. Among these means education holds a primary position. The second chapter brings Newman's attitude towards the utilitarian concept of university education, and the third chapter deals with the influence of the university on the moral formation of the individual.

Keywords: education, university, Newman, intellectual development, moral formation, utilitarianism.

* Maja Poljak, Ph. D., Department of Philosophy, University of Zadar, Obala kralja Petra Krešimira IV. br. 2, 23000 Zadar, Croatia, mpoljak@unizd.hr 